\title{
Preliminary Assessment of Corbicula fluminea in Saiburi River, Southern Thailand
}

\author{
ZAWEEN NAJJAH MOHAMAD SHAMSUL ${ }^{1}$, AWENG EH RAK ${ }^{1 *}$, SUKREE \\ HAJISAMAE $^{2}$, SHARIFAH AISYAH SYED OMAR ${ }^{1 *} \&$ LIYANA AHMAD AFIP $^{3}$
}

${ }^{1}$ Faculty of Earth Science, Universiti Malaysia Kelantan, Jeli Campus Locked Bag No. 100, 17600 Jeli, Kelantan, Malaysia; ${ }^{2}$ Department of Fisheries Science, Faculty of Science and Technology, Prince of Songkla University Pattani, Rusamilae, Mueang Pattani District, Pattani 94000, Thailand; ${ }^{3}$ Centre for Language Studies and Generic Development, Universiti Malaysia Kelantan

*Corresponding authors: aweng@umk.edu.my; shaisyah.syedomar@gmail.com

\begin{abstract}
This study was conducted to determine the habitat characteristics and availability of existing C. fluminea in Saiburi River, which is in the southern part of Thailand. Saiburi River is one of the locations for $C$. fluminea harvesting in Southeast Thailand. In total, 329 individuals of $C$. fluminea were collected from Saiburi River by dragging the dredge using a clam dredge, approximately $1 \mathrm{~m}$ measured by the quadrat. The most abundant size found ranged between 11 and $20 \mathrm{~mm}$ in length with the highest density of $290 \mathrm{per} \mathrm{m}^{2}$ and mean density of $196 \mathrm{per} \mathrm{m}^{2}$. In this study, a total of seven physical, chemical and biological parameters $(\mathrm{pH}$, temperature, dissolved oxygen, nitrate, phosphate, sediments and phytoplankton) were analyzed in five selected sampling points. The results for $\mathrm{pH}$ $(6.7+0.15)$; temperature $\left(34^{\circ} \mathrm{C}\right)$; dissolved oxygen $(8.1+0.10 \mathrm{mg} / \mathrm{L})$; nitrate $(0.1+0.7 \mathrm{mg} / \mathrm{L})$; phosphate $(0.1+0.7$ $\mathrm{mg} / \mathrm{L}$ ); sediments (loamy sand); phytoplanktons (29 species belong to 22 different families) were recorded. Therefore, the present report provides the information on the habitat of $C$. fluminea.
\end{abstract}

Keywords: Corbicula fluminea, water quality, habitat, phytoplankton, Saiburi River

\section{INTRODUCTION}

Corbicula fluminea is a clam, which used to be a famous traditional snack for local in Thailand and Kelantan, Malaysia, has increased in its market demand recently (Zalina, 2014). Therefore, over exploitation and harvesting of this clam by villagers may affect its population in river. Moreover, some places and rivers are facing habitat modification and destruction from the construction of dams and canalization. These result in changes in water depth due to the flow changes and changes in fine particle deposition (silt and sand) (Bogan, 2008). These activities also contribute to the extinctions of $C$. fluminea This is because $C$. fluminea depends on sediment for its habitat and burrowing activities. The composition of organic matter and phytoplankton is also important as they serve as a food source for this clam. The clam is usually harvested by using a clam dredge or a basket without a standardised harvesting size. In this case, the survival rates for juveniles of $C$. fluminae may decrease.
C. fluminea has rapid growth, earlier sexual maturity, short life span, high fecundity and has association with human activities (Sousa, 2008). C. fluminea can influence the habitat heterogeneity by modifying the diversity of the macrozoobenthic assemblages favoring sessile crustaceans, gastropods and insects, and negatively affecting other bivalve species (Ilarri et al., 2012). The life span of this species is generally 2 to 3 years and during their life span, clams seem to reproduce once or twice a year (Rosa, 2013). Juveniles reach maturation within 3 to 6 months and are generally 6 to $10 \mathrm{~mm}$ in length. The juveniles use the mucilaginous byssal thread to anchor themselves to any hard surface and substrates or use the thread to be carried through the water column by water currents and dispersed at long distance (KramerWilt, 2008). Several researches have been conducted on $C$. fluminea for the effect of temperature, $\mathrm{pH}$, dissolved oxygen, substrates, organic matter and food preference. 
The results showed that this clam did not prefer extreme temperature (Rosa et al., 2012) and $\mathrm{pH}$ (Sousa et al., 2008), but survived in low dissolved oxygen. The substrate types and compositions were shown to be related to the organic matter composition, which can affect the composition of this clam.

Phytoplankton are considered as a food source for bivalves, therefore its abundance in shallow area is strongly controlled by bivalve grazing (Arapov et al., 2010). Bivalves can also significantly reduce the effect of eutrophication by grazing (Pigneur et al., 2014). This study focused on the clam density, habitat conditions and phytoplankton presence in Saiburi River.
Hopefully, it will help in sustaining the productivity of this clam and overcome over exploitation issues. On the other hand, this may also give some information on potential solutions to achieve and satisfy the local market demand in Thailand and Malaysia.

\section{MATERIALS AND METHODS}

Saiburi River is located in the east coast of the Southern Thailand. This river is easily accessed by villagers and one of the common areas for harvesting $C$. fluminea by locals. Therefore, five points were selected at Saiburi River as the study areas. Figure 1 shows the map of Saiburi River, Thailand.

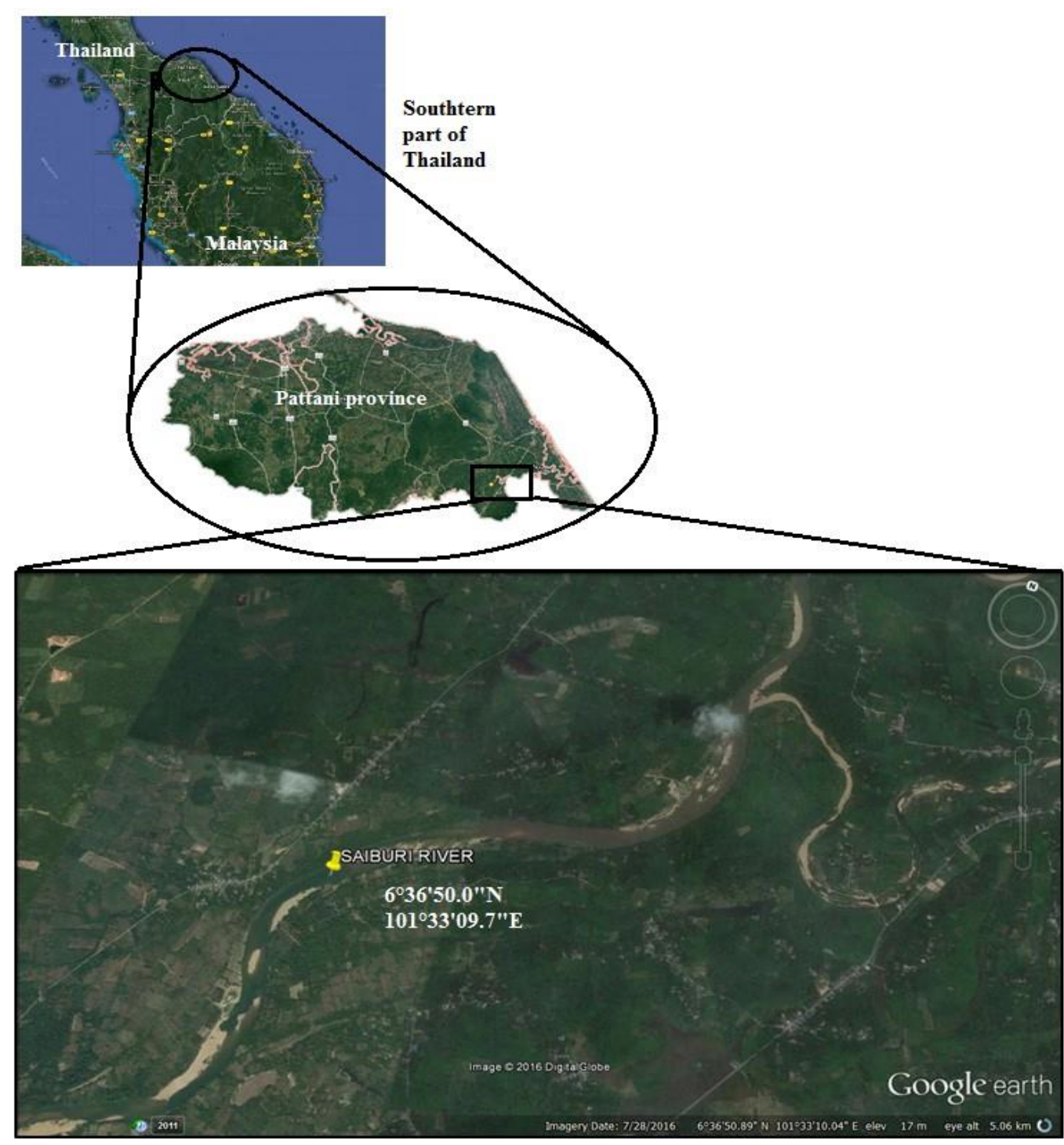

Figure 1. Map of Southern Thailand, Pattani Province and Saiburi River. 


\section{Water Quality Sampling and Analysis}

Water samples $(800 \mathrm{~mL})$ were collected and analyzed. Four parameters were measured in the laboratory, namely dissolved oxygen, nitrate, phosphate and phytoplankton. Dissolved oxygen was measured by using Winkler method (Bartram \& Ballance, 1996). Meanwhile, $\mathrm{pH}$ and temperature were measured by in-situ instruments, namely Hannah Portable $\mathrm{pH}$ meter and a mercury-in- glass thermometer, respectively. Sediment samples were collected by using a metal scoop for about 1 to 6 inches in depth and transferred into a sampling plastic bag and preserved in temperature of $4^{\circ} \mathrm{C}$.

The analyses of dissolved oxygen, nitrate and phosphate were carried out by using the standard method (American Public Health Association, 1999; Bartram \& Ballance, 1996). The experimental analysis for the sediments, namely particle size distribution, was performed using Pipette Method to determine the percentage of the sand, silt and clay of each sample. Based on the percentage, the types of soil for each sample were determined by using United States Department of Agriculture (USDA) particle size distribution and textural classification chart (Dinakaran \& Krishnayya, 2011).

\section{Corbicula fluminea and phytoplankton sampling and analysis}

C. fluminea were collected in five replications from five selected points in this river. The $C$. fluminea were collected by dragging the dredge, using a clam dredge approximately $1 \mathrm{~m}$ measured by the quadrat. All $C$. fluminea that remained in the dredge were counted and then put in a plastic bag to be brought back to the laboratory. C. fluminea were measured by using a Vernier caliper for its length and height. The color of the internal and external shell of the $C$. fluminea was observed to identify the shell morphology (Menninger, 2012).

However, the excessive amount of phosphate may cause depletion of dissolved oxygen because of the decaying process by the aquatic plants (Minnesota Pollution Control Agency, 2008). The phosphate in Saiburi River might be originated from the irrigation water whereby the continuous use of water in the irrigation system would indirectly release the diluted phosphorus from fertilizer and soil into the stream (Yolthantham, 2007). However, the concentration of phosphorus in this river was not according to the NWQI standard, since it exceeded $0.2 \mathrm{mg} / \mathrm{l}$, which is the maximum level for Class II river in Malaysia (Lomoljo et al., 2009).

The phytoplankton samples taken from approximately $300 \mathrm{~L}$ of river water were filtered through a phytoplankton net $(40 \mu \mathrm{m})$. The water samples were stored in $50 \mathrm{~mL}$ PTFE plastic bottles and then preserved in $5 \%(\mathrm{v} / \mathrm{v})$ formalin solution before they were brought to the laboratory. The phytoplankton in $1 \mathrm{~mL}$ of the water samples were observed under the microscope with $4 \mathrm{x}$ or $10 \mathrm{x}$ magnification by using Sedgewick-Rafter Cell to identify phytoplankton samples. The identified samples in the different water sources for each category were then scored for absence (-) or presence $(\sqrt{ })$ of phytoplankton. Identification was made through comparative morphology and description using relevant text books, manuals and articles (Nguetsop et al., 2007; Bellinger \& Siegee, 2010).

\section{RESULTS AND DISCUSSION}

\section{Water quality}

The mean $\mathrm{pH}$ value at study area was $6.7 \pm 0.15$. Water temperature in Saiburi River was constant at $34^{\circ} \mathrm{C}$. National Exotic Marine and Estuarine Species Information System (2015) stated the temperature tolerance range for Asian clam's survival and reproduction was $2-34^{\circ} \mathrm{C}$ and 18 $30^{\circ} \mathrm{C}$, respectively. Therefore, this condition might be one of the reasons of the decline of this clam population in this river as the temperature of this river is quite high for the clam reproduction. However, the sampling duration was carried out at noon and the absence of canopy cover at Saiburi River area might be the reason for the high temperature results. Besides, the dissolved oxygen level is considered relatively high, which is approximately $8.1 \pm 0.10$ $\mathrm{mg} / \mathrm{L}$. This indicates that the temperature of water might be cooler at other times as the oxygen content increases with the decrease of temperature.

The mean concentrations of nitrate and phosphate were $0.1 \pm 0.07 \mathrm{mg} / \mathrm{L}$ and $0.1 \pm 0.07$ 
$\mathrm{mg} / \mathrm{L}$, respectively. The excretion process by $C$. fluminea may discharge soluble ammonium, nitrite, nitrate, phosphate and insoluble wastes. This phenomenon will stimulate the growth of planktons and aquatic plants that serve as food for aquatic animals.

\section{Substrates composition}

Substrates at Saiburi River composed of fine sand, clay and silt. The results showed that, $87 \%$ of the sediment at Saiburi River was classified as fine sand, $12 \%$ as clay and $1 \%$ as silt. The structure and porosity of the soil influenced the oxygen in the soil itself. Therefore, small pores in clay may limit the air circulation thus resulting a low oxygen level in the soil. Chase et al. (2017) mentioned that, this clams preferred a habitat with fine or coarse sand substrates rather than mud or bare concrete. Colwell et al. (2017) also found that substrates influence the distribution of this clam. $C$. fluminea grow up with the ability to efficiently meet their metabolic needs by collecting food from their substrates (Noreña et al., 2015). As for $C$. fluminea, which is a pedal feeder, it will take up fine particulates from the substrates by using ciliary tracts on their foot. The availability of nutrients and organic matters in the substrates will influence the density of $C$. fluminea as this species relies heavily on those components as a food source other than phytoplankton.

Furthermore, substrate type is also important for the juveniles of $C$. fluminea and other infauna bivalve to attach their byssal thread and preventing them to be transported along with the water current (Michael \& Joe, 2014). The juveniles rely on the temporary attachment of the byssal. However, statistical analysis done by Chase et al. (2017) showed that substrate was not the major factor that influences the distribution of this Asian clam.

Even though, they found the highest densities of $C$. fluminea at substrates with more sand at shallow area. On the other hand, they claimed some studies found that substrate type is an important factor that contributes to the assemblages and distribution of benthic organisms.

\section{Phytoplankton}

In total, 12 families and 15 species of phytoplankton were found for five phylums such as Ochrophyta, Miozoa, Charophyta, Bacillariophyta, and Cyanobacteria. The 12 families were identified as Fragilariaceae, Ceratiaceae, Chroococcaceae, Closteriaceae, Desmidiaceae, Cymbellaceae, Oscillatoriaceae, Melosiraceae, Bacillariaceae, Volvocaceae, Surirellaceae, and Sphaerocystidaceae. The occurrence of diverse species of phytoplankton in Saiburi River may be one of the factors that contribute to the availability of $C$. fluminea. High amount of phytoplankton in turn leads to high availability of food source for this species and thus will enhance their growth (Chase et al., 2017). Pigneur et al. (2014) reported that there was about $70 \%$ of loss of phytoplankton biomass due to $C$. fluminea filtration and represented a $60 \%$ declination in comparison to the area without this species. The phytoplankton available in the water bodies can also act as an indicator for the water quality. However, the phytoplankton diversity and distribution were not within the scope of this research.

\section{Corbicula fluminea}

To date, there was no study reported on the population survey of $C$. fluminea at Saiburi River. Therefore, determination of the population decline cannot be done at this river. However, this site was heavily emphasized by previous and present harvesters (Zalina, 2014). This is due to the criteria of Saiburi River, which is very shallow and easily accessible to the villagers. The depth of the river is approximately between 20 and $60 \mathrm{~cm}$. The shallow nature of the river enables the use of either baskets or clam dredges for the clam collection, which has become the conventional method practiced by the villagers.

The results showed that, a total of 329 individuals were collected with the mean of clam density of $196 \mathrm{clams} / \mathrm{m}^{2}$. Table 1 shows the collection of Asian clams at each station whereby Figure 2 shows the clams found at Saiburi River. However, these results showed a relatively lower density of clams compared to the existing data obtained at temperate region whereby the availability of $C$. fluminea was seen in thousands per square meter. This was due to the ability of the species as filter-feeders that utilise pedal-feeding functions, and also their wide habitat tolerance (Hakenkamp et al., 2001; Chase et al., 2017). 
The results showed that the range of clams collected was between 8.9 and $19.5 \mathrm{~mm}$. However, the majority of the clam collected ranged between 11 and $20 \mathrm{~mm}$ class sizes. Meanwhile, clams from 11 to $15 \mathrm{~mm}$ class size was found to have the highest length of frequency distribution $(n=203)$ followed by the clams from 16 to $20 \mathrm{~mm}$ size $(n=123)$. Only three clams for the class size of 6 to $10 \mathrm{~mm}$ was found and no clam was collected for the class size of 20 to $23 \mathrm{~mm}, 1$ to $5 \mathrm{~mm}$ and 26 to $30 \mathrm{~mm}$.

According to National Exotic Marine and Estuarine Species Information System (2015), the minimum sizes of male and female adult for Asian clams are 8 and $13.4 \mathrm{~mm}$, respectively. Meanwhile, the typical size is $20 \mathrm{~mm}$ while the maximum size is $60 \mathrm{~mm}$ for both male and female clams.

On the other hand, the structure of the population was analyzed according to the following size classes (shell length): small individuals ( 1 to $10 \mathrm{~mm}$ ), medium individuals (11 to $20 \mathrm{~mm}$ ) and large individuals (21 to 30 $\mathrm{mm}$ ) (Reyna et al., 2013). The samples collected at Saiburi River consist of $99 \%(n=326)$ of medium size clams and only $1 \%(n=3)$ from the small size class. No clam from the large size class was found.

Table 1. Density of $C$. fluminea at Saiburi River.

\begin{tabular}{lll}
\hline Station & $\begin{array}{l}\text { No of clam } \\
\text { measured }\end{array}$ & $\begin{array}{l}\text { Density } \\
\text { per } \mathrm{m}^{2}\end{array}$ \\
\hline 1 & $44 \pm 2.7$ & 131 \\
2 & $28 \pm 0.9$ & 84 \\
3 & $97 \pm 7.8$ & 290 \\
4 & $64 \pm 6.9$ & 191 \\
5 & $96 \pm 8.7$ & 280 \\
\hline Mean & 65.8 & 196 \\
\hline
\end{tabular}

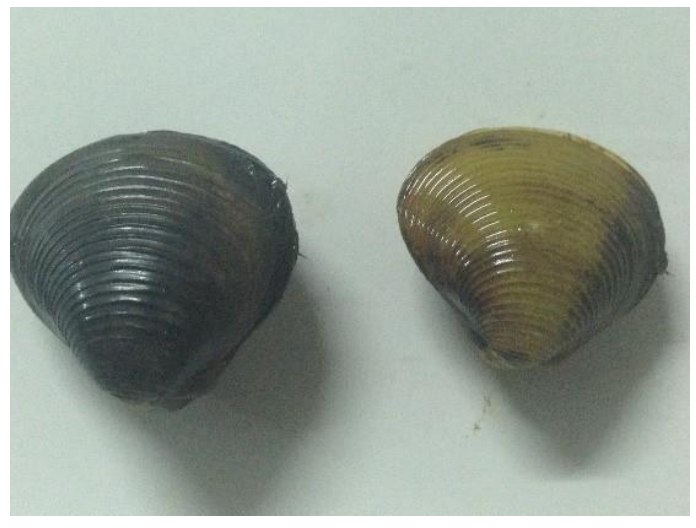

Figure 2. Two different shell morphologies of $C$. fluminea.

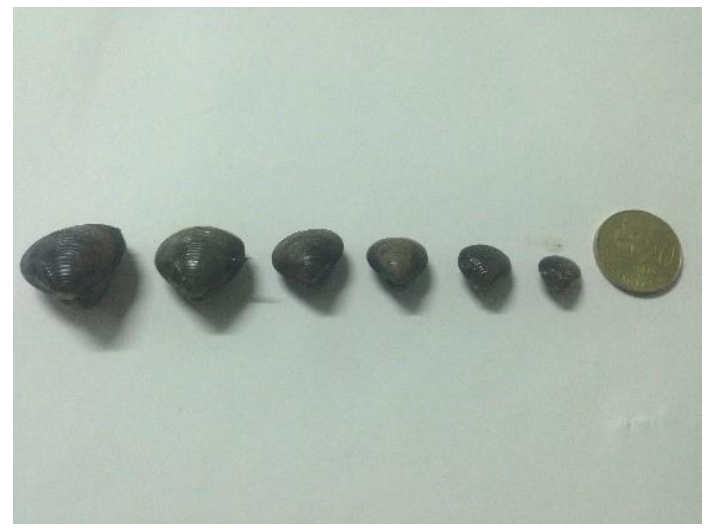

Figure 3. Size variation of $C$. fluminea shells. 


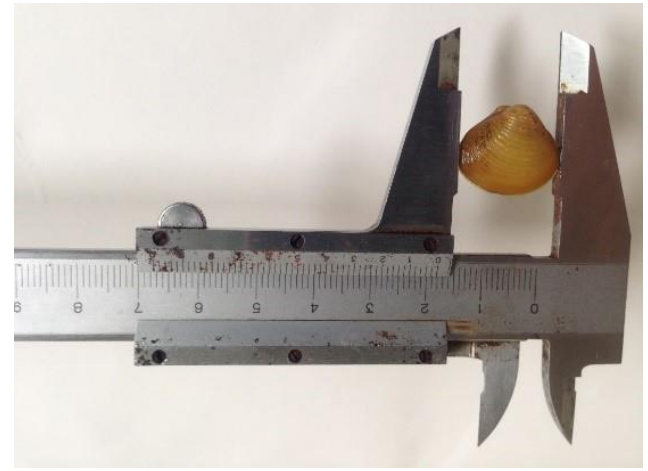

Figure 4. Measurement of the length of $C$. fluminea using a Vernier caliper.

The trend of the size classes showed a significant increase of clam of medium size and a significant decrease started from clam with the size of $16 \mathrm{~mm}$ to $30 \mathrm{~mm}$. Most of the bivalves including $C$. fluminea tend to burrow themselves in the sediment. Conversely, a juvenile can be easily carried away by the current than bigger individuals (Sousa, 2008). Michael et al. (2014) claimed in their assessment, that smaller clams have a high probability to be transported along the water current to the downstream. This might be the reason for the less collection of $C$. fluminea with small size. Figure 3 shows the variation of clam by size. Figures 4 and 5 show the measurement for length and width of the clam.

For the medium sized clams, they have the highest frequency distribution in this river. The abundant of this clam size ranging from 11 to 15 $\mathrm{mm}$ and 16 to $20 \mathrm{~mm}$ size class. Besides the high reproduction, $C$. fluminea also have a physical characteristic that gives them higher capacity for locomotion and efficient burrowing. This burrowing activity helps them to avoid predators either fish and also from human and usually, they will burrow themselves 10 to $15 \mathrm{~cm}$ in the sediment.

Aforesaid, the sampling result showed that the distribution of clam from size class 21 to $25 \mathrm{~mm}$ and 26 to $30 \mathrm{~mm}$ was very poor. There were significant gaps between the total numbers of clams in medium size compared to the large size. The dramatic decline in large size of clams is because of the routinely harvesting activity by the villagers to be sold and consumed and the

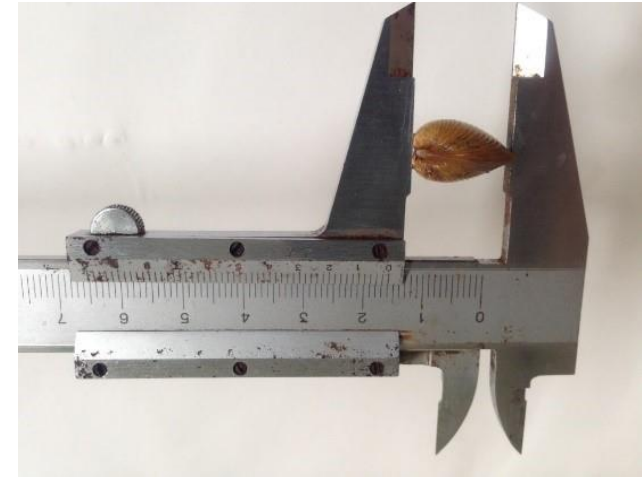

Figure 5. Measurement of the height of $C$. fluminea using a Vernier caliper.

larger size clam preferably collected rather than a medium and small size clams. On the other hand, the $C$. fluminea minimum lifespan is 1 year and maximum is 4 years (National Exotic Marine and Estuarine Species Information System, 2015). Therefore, the lack of larger size clams might also be caused by the harvesting activities as the clam does not have much time to grow larger.

\section{CONCLUSION}

In conclusion, this study found that the Saiburi River which is sandy and shallow which is suitable for $C$. fluminea population. The water quality in Saiburi River was found in the range of environmental tolerance, which is $\mathrm{pH}(6.7+0.15)$; temperature $\left(34^{\circ} \mathrm{C}\right)$; dissolved oxygen $(8.1+0.10$ $\mathrm{mg} / \mathrm{L}) ;$ nitrate $(0.1+0.7 \mathrm{mg} / \mathrm{L}) ;$ phosphate $(0.1+0.7 \mathrm{mg} / \mathrm{L})$. On the other hand, the diverse phytoplankton indicates the food availability for $C$. fluminea population. The most found clams were in the size of $11-20 \mathrm{~mm}$ in length. However, the larger size of $C$. fluminea is scarce and was rarely collected because of uncontrolled harvesting activities as the area is a shallow river that can be easily accessible to human. Meanwhile the small clams may decline due to water flow. Therefore, further study on environmental tolerance at Asian area should be carried out to gain better understanding and helps the distinction of this clam from uncontrolled harvesting and habitat disturbance. This is because most of the study done was about Asian clam as invasive species at temperate ecoregion. 


\section{ACKNOWLEDGEMENTS}

We are grateful to Ministry of Higher Education, Malaysia, for financial support to this research work through the Trans Disciplinary Research Grant Scheme (TRGS: R/TRGS/ A08.00/ 00244A/005/2016/000389. We are also thankful to the management of Universiti Malaysia Kelantan for sponsoring the student mobility programme abroad and also the management of the Faculty of Science and Technology, Prince of Songkhla University, Thailand for supervising the students as well as lending the laboratory instruments for the completion of this research.

\section{REFERENCES}

American Public Health Association (APHA), American Water Works Association (AWWA), and Water Environment Federation (WEF). (1999). Standard Methods for the Examination of Water and Wastewater $20^{\text {th }}$ Edition.

Arapov, J., Ezgeta-Balic, D., Peharda, M. \& Gladan, Z.N. (2010). Bivalve feeding - How and what they eat? Ribarstvo, 68(3): 105-116.

Bartram, J. \& Ballance, R. (Eds.). (1996). Water quality monitoring: a practical guide to the design and implementation of freshwater quality studies and monitoring programmes. CRC Press.

Bogan, A.E. (2008). Global diversity of freshwater mussels (Mollusca, Bivalvia) in freshwater. Hydrobiologia, 595(1): 139-147.

Bellinger, E.G. \& Siegee, D.C. (2010). Freshwater algae: Identification and use as bioindicators. West Sussex: John Wiley and Sons Ltd. Pp. 271

Chase, H.P., Matthew, N., Waters S. \& Stephen, W.G. (2017). The distribution and ecological role of Corbicula fluminea (Müller, 1774). BioInvasions Records, 6(1): 39-48.

Colwell, H., Ryder, J., Nuzzo, R., Reardon, M., Holland, R. \& Wai, H.W. (2017). Invasive Asian clams (Corbicula fluminea) recorded from 2001 to 2016 in Massachusetts, USA, Management of Biological Invasions, 8(4): 507-515.

Dinakaran, J. \& Krishnayya, N.S.R. (2011). Variations in total organic carbon and grain size distribution in ephemeral river sediments in western India. International Journal of Sediment Research, 26(2): 239-246.
Hakenkamp, C.C., Ribblett, S.G., Palmer, M.A., Swan, C.M., Reid, J.W. \& Goodison, M.R. (2001). The impact of an introduced bivalve (Corbicula fluminea) on the benthos of a sandy stream. Freshwater Biology, 46:491-501.

Ilarri, M. \& Sousa, R. (2012). Corbicula fluminea Müller (Asian clam). In Francis, R.A. (Ed.), A handbook of global freshwater invasive species. Earthscan Ltd. Pp, 173-183.

Kramer-Wilt, E. (2008). Corbicula fluminea (O. F. Müller, 1774) - Asian clam. Aquatic invasion ecology, 16. animals: selection versus resistance. Canadian Journal of Fisheries and Aquatic Sciences, 59: 1235-1244.

Lomoljo, R.M., Ismail, A. \& Yap, C.K. (2009). Nitrate, ammonia and phosphate concentrations in the surface water of Kuala Gula Bird Sanctuary, west coast of Peninsular Malaysia, Pertanika Journal Tropical Agriculture Science, 32(1): 1-5.

Michael, M. \& Joe, C. (2014). Risk assessment of Corbicula fluminea: Non-native species risk assessment. National Biodiversity Data Centre. http://nonnativespecies.ie/wpcontent/uploads/201 4/03/Corbicula-fluminea-Asian-Clam1.pdf. Downloaded on 27 December 2017.

Menninger, D. (2012). Asian clam (Corbicula fluminea). New York Invasive Species Information.http://nyis.info/?action=invasive_det ail\&id=52. Downloaded on 27 December 2017.

Minnesota Pollution Control Agency. (2008). Nutrients: Phosphorus, nitrogen sources, impact on water quality - A general overview. https://www.pca.state.mn.us/sites/default/files/wq -iw3-22.pdf. Downloaded on 27 December 2017.

National Exotic Marine and Estuarine Species Information System. (2015). Chesapeake Bay Introduced Species Database: http://invasions.si.edu/nemesis/CHIMP.jsp?Speci es_name $=$ Corbicula+fluminea. Downloaded on 27 December 2017.

Nguetsop, V.F., Fonko, U.T., Assah, V.M.D., Nangtson, M.N. \& Pinta, J.Y. (2007). Relationship between algae and physicochemical characteristics of water in wetlands and water bodies, Cameroon. Journal of Experimental Biology, 3:70-79.

Noreña, C., Damborenea, C. \& Brusa, F. (2015). Ecology and general biology. In Thorp, J.H. \& Rogers, C.D. (Eds.), Thorp and Covich's freshwater invertebrates. Academic Press. 
Pigneur, L., Elodie, F., Kathleen, R. Etienne, E., Deliego, J., Joseph, S.S., Karine, V.D. \& Descy, J. (2014). Impact of invasive Asian clams, Corbicula spp., on a larger river ecosystem. Freshwater Biology, 59(3): 573-583.

Reyna, P.B., Morán, A.G. \& Tatián, M. (2013). Taxonomy, distribution and population structure of invasive Corbiculidae (Mollusca, Bivalvia) in the Suquía River basin, Córdoba, Argentina. Iheringia, Série Zoologia, 103(2): 77-84.

Rosa, I.C., Pereira, J.L., Costa, R., Gonçalves, F. \& Prezant, R. (2012). Effects of upper-limit water temperatures on the dispersal of the Asian clam Corbicula fluminea. PLOS ONE, 7(10): 1-10.

Rosa, I.C. (2013). The Asian clam: Dispersal, impacts and potential benefits. Managing the invasion by the biofouler Asian clam Corbicula fluminea: improvement of control methods and taking profits from the species abilities (Ph.D. Thesis). University of Oporto and University of Aveiro.
Sousa, R., Antunes, C., \& Guilhermino, L. (2008). Ecology of the invasive Asian clam Corbicula fluminea (Muller, 1774) in aquatic ecosystems: an overview. International Journal of Limnology, 44:85-94.

Sousa, R.G. (2008). Factors contributing to the invasive success of Corbicula fluminea (Müller, 1774) (Ph.D. Thesis). Universidade do Porto.

Yolthantham, T. (2007). Water quality monitoring and water quality situation in Thailand. Inland Water Division. Pollution Control Department (PCD) Thailand.

Zalina, C.M. (2014). Characterization of bacteria coliform in smoked and live Asian clam (Corbicula fluminea) sold in Kota Bharu, Kelantan (Master Thesis). Universiti Malaysia Kelantan. 